\title{
Epileptic seizures in patients with COVID-19: A systematic review of early evidences
}

Roy $\mathrm{B}^{1 *}$, Banerjee $\mathrm{I}^{2}$

*Corresponding author:

Dr Bedanta Roy, Ph.D.

Senior Lecturer, Department of Physiology, Faculty of Medicine, Quest International University, Ipoh, Perak, Malaysia

Email: bedanta.roy@gmail.com ORCID

Information about the article:

Received: Oct. 05, 2020

Accepted: April 04, 2021

Published online: July 11, 2021

Cite this article:

Roy B, Banerjee I. Epileptic seizures in patients with COVID-19: A systematic review of early evidences. Journal of Biomedical Sciences. 2021; 8(1):33-44

\section{Publisher}

Nepal Health Research Society, Bahundhara -6, Gokarnesowor Municipality, Kathmandu, Nepal eISSN 2382-5545, ISSN 2676-1343 (Print)

(C) The Author(s). 2021

Content licensing: CC BY 4.0

\section{ABSTRACT \\ Background}

Global emergence of SARS-CoV-2 surfaced neurological complications amongst the patients. COVID-19 resembles with other coronavirus strains follows a trend of neurological complication, damage and encephalopathy, which entails considerable risks, requires attention for the neurologists. This is, to our knowledge, the first systematic review of the literature to investigate solely to elucidate the seizure spectrum by unfolding epileptogenicity of the SARS $\mathrm{CoV}-2$ and potential pathways of neuroinvasion.

\section{Methods}

A systematic literature search was performed in PubMed and Embase database following standard guidelines, using specific keywords based on epileptic seizure onset described from December 01, 2019, to July 17, 2020

\section{Results}

A total of 17 studies were included ranging from case reports, series of cases, multicentre cross-sectional study with the first-time onset of seizure associated with an epileptic origin. We excavated causes of complex COVID19 related neurological manifestations, e.g., cerebrovascular diseases, encephalitis, demyelinating lesions, cytokine storm and proposed routes of SARS-CoV-2 entry into the nervous system to understand the mechanism of an epileptic seizure.

\section{Conclusion}

COVID-19 is a potent neuropathogen which causes the new onset of epileptic seizures should get diagnostic recognition to evade possible deterioration of neurological conditions. However, more shreds of evidence from the future will further elucidate the epileptogenic potential of the pandemic.

\section{Keywords}

Brain diseases, Coronavirus infections, Epilepsia Partialis Continua, Epilepsy, neurologic manifestations, SARS-CoV2, Seizures 


\section{Background}

Severe acute respiratory syndrome coronavirus-2 (SARS$\mathrm{CoV}-2$ ) is recently emerged human pandemic stormed the whole world. The virus was identified as a beta coronavirus is dissimilar with severe acute respiratory syndrome coronavirus (SARS-CoV) and Middle East respiratory syndrome coronavirus (MERS-CoV), hence got a distinct identity. The clinical presentation of SARS-CoV-2 is acute respiratory distress syndrome (ARDS) and viral pneumonia $[1,2]$. The disease was first surfaced in Wuhan, Hubei Province, since December 12, 2019, in China, conceivably linked to the Huanan Seafood Wholesale Market located in Jianghan District [3]. The virus was named as Coronavirus disease 2019 "COVID-19" by the World Health Organization (WHO), affected 216 countries with $2,102,6758$ confirmed cases and 75,5786 deaths as of August 16, 2020 [4]. The spread of this virus and ongoing devastation around the world shows no evidence of ending of this global pandemic and it impacted deadly on economic, financial, social, and mental wellbeing on the humanity.

Shortness of breath, fever, and cough reported since the beginning of the pandemic [1, 2], but clinical manifestations of SARS-CoV-2 are not limited to the respiratory system; it infects the nervous system too. Mao et al. published the first hospital-based report on the SARS-CoV-2 infected patients revealed that $36.4 \%$ of the patients had neurological complications: CNS (53 [24.8\%]), PNS (19 [8.9\%]). Dizziness, headache, taste and smell impairment was the most common symptoms reported [5]. Growing shreds of evidence of nausea, vomiting, myalgia, asthenia, dizziness, and reduced consciousness imply the viral neuroinvasive potential which increases with the severity of infection [5, 6]. SARS-CoV-1 outbreak in 2002-2003 documented numerous neurological manifestations ranging from moderate complications like seizures, status epilepticus, myopathy, to severe consequences stroke and polyneuropathy $[7,8]$.

This systematic review aims to outline a spectrum of the seizures and epileptic symptoms of SARS-CoV-2 infected patients and enlighten the viral invasion to CNS and mechanism of epileptogenicity.

\section{Material and methods}

A systematic literature search was conducted from December 01, 2019, to July 17, 2020, in PubMed and Embase database. We followed the recommendations of the Preferred Reporting Items for Systematic Review and MetaAnalysis (PRISMA) protocol [9]. The search strategy was developed by an expert panel of neurologists and neurophysiologists. Search terms included "COVID-19" OR “SARS-CoV-2" OR "2019-nCoV” OR "novel coronavirus" in conjunction with "epilepsy" OR "Seizure." (Figure 1).

Articles written in the English language were included for this review. The authors carefully examined the list of references in the included studies to confirm the literature saturation. All authors scanned the titles and full-text reports independently against the standard search criteria for the systematic review to identify the eligibility and inclusion. Disagreement pertaining for the inclusion of articles were resolved through the discussions. The authors extracted the following data from all included studies: Author/year, age, gender, design, the interval of COVID-19 symptom onset and first seizure, clinical presentation, neurological manifestations, diagnostic findings, interventions, and limitations. The level of evidence and quality of the research was also carefully observed. Reference management was done by EndNote X5 software (Clarivate Analytics, Boston, MA, USA). This systematic review protocol was not registered earlier. We mostly followed the WHO recommended gold standard guidelines (epidemiological history, clinical symptoms, and laboratory or radiological findings) to consider the articles in our study. All cases included in this review were confirmed cases of SARS-CoV-2, which was diagnosed by SARSCoV-2 PCR testing using a nasopharynx swab. We reviewed the clinical researches, including original articles, case series, and case reports, for neurological involvement by COVID-19 on the incidence of epilepsy and organized them into tables.

\section{Results}

Through our search strategy, we have identified a total of 160 abstracts. After exclusion and eligibility of full text, 17 articles were selected for systematic review, involved seizures, or epilepsy as a new-onset due to SARS-CoV-2 infection. Among these articles, 12 were case reports; four were case series, and one study was a multicentre crosssectional study. Table- 1 and Table- 2 shows the summary of the included studies [5, 10-25].

All studies were critically analyzed based on the standard diagnosis for epilepsy (e.g., EEG, head CT /MRI, CSF analysis). We also included CSF-PCR to obtain information for neuroinvasion of SARS-CoV-2 and the intervention strategy towards the administration of Anti-epileptic drugs. Besides, we rigorously reviewed a few relevant literature (26-30) to understand the mechanism of entry of SARSCoV-2 in CNS summarized in Figure 2.

Figure 2: Explains the possible routes of SARS-CoV-2 entry in the nervous system.

2a. shows the hematologic route where viral particles cross the endothelial cells of the blood-brain barrier (BBB) either directly or enter by using the infected cells of the reticuloendothelial system (RE) or lymphocyte as a vehicle through the paracellular route.

$2 \mathrm{~b}$. shows the neurologic route where virus enters in the olfactory epithelium, olfactory bulb and later enters in the olfactory tract. Retrograde axonal transport and CoVs clathrin-dependent endocytotic/exocytotic pathway may help in this process. 


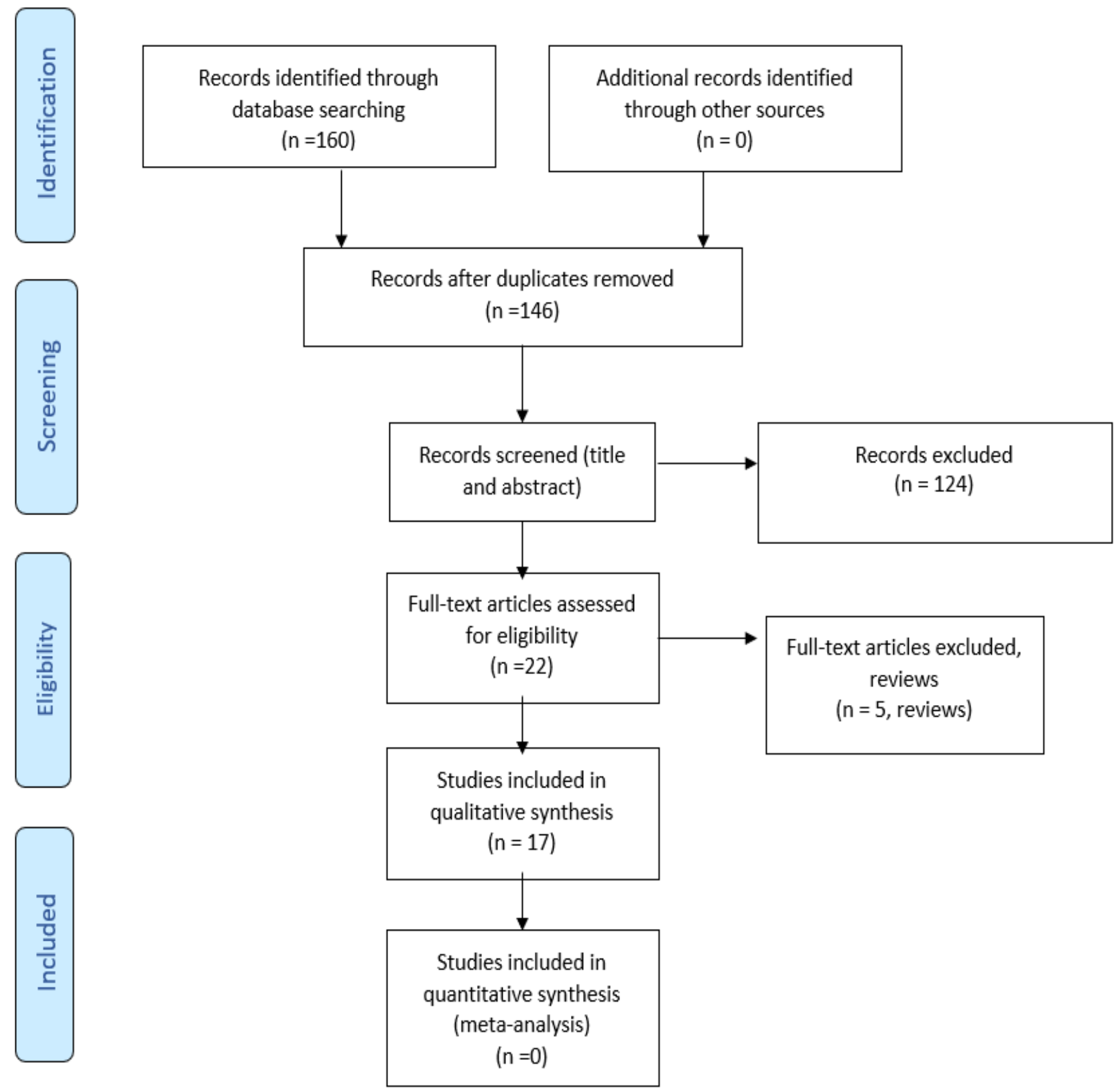

Figure 1: Inclusion of articles by Preferred Reported Items for Systematic reviews 


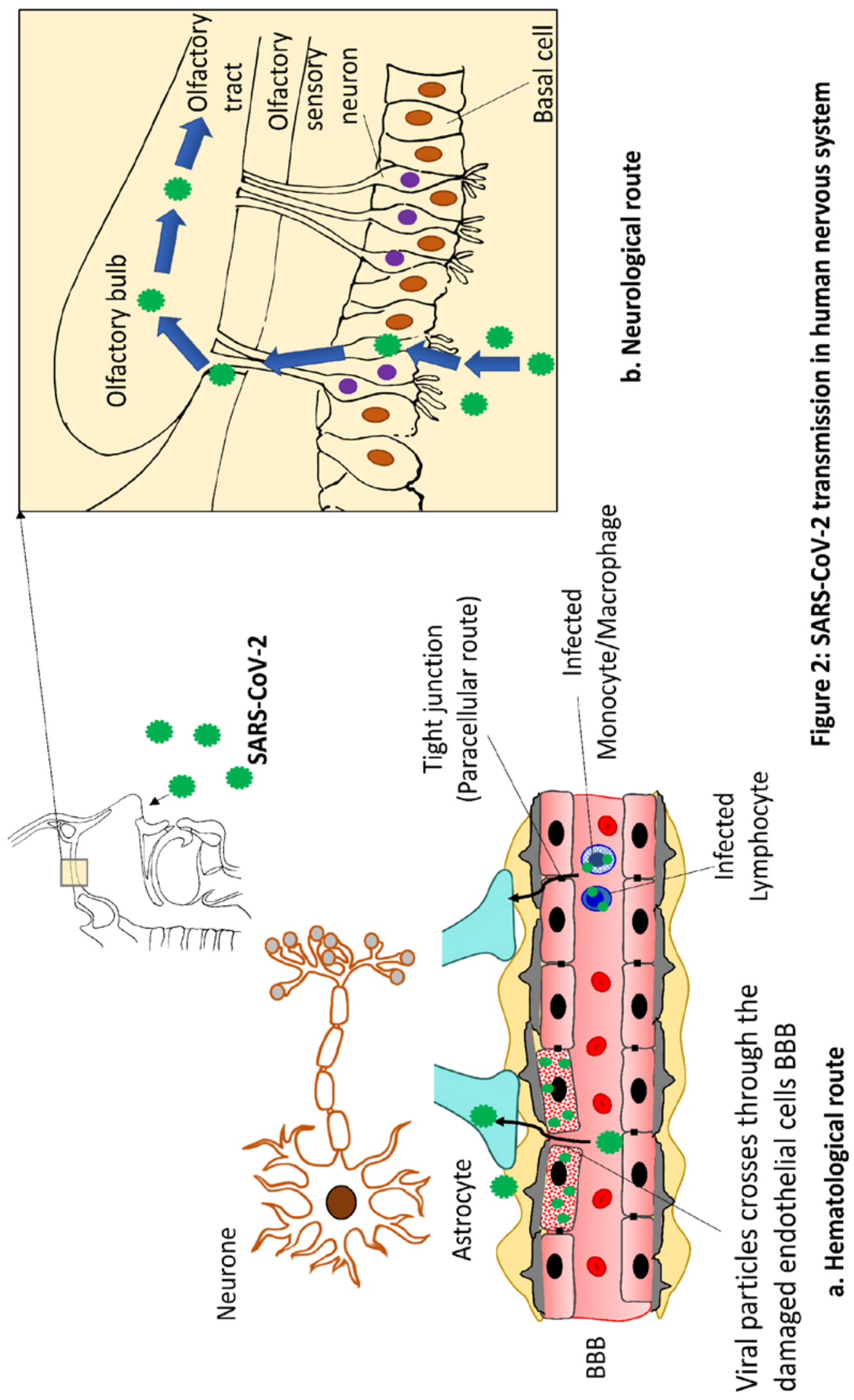


Table 1: Summary of the studies, infection interval and clinical presentation

\begin{tabular}{|c|c|c|c|c|c|}
\hline $\begin{array}{l}\text { Author, } \\
\text { year }\end{array}$ & $\begin{array}{l}\text { Age(years)/mean/ } \\
\text { mean }[S D] \text {, } \\
\text { Gender }\end{array}$ & Design & $\begin{array}{l}\text { No }(\% \text { in } \\
\text { total } \\
\text { participants) }\end{array}$ & $\begin{array}{l}\text { Interval of } \\
\text { COVID } \\
\text { symptom onset } \\
\text { and first } \\
\text { seizure activity } \\
\text { (days) }\end{array}$ & $\begin{array}{l}\text { Clinical presentation towards epileptic } \\
\text { manifestations } \\
\text { /Seizure description/ } \\
\text { characteristics }\end{array}$ \\
\hline $\begin{array}{l}\text { Lyons et al. } \\
2020\end{array}$ & $20, \mathrm{M}$ & Case report & 1 & +3 & $\begin{array}{l}\text { Light-headedness with blurred and double } \\
\text { vision, lower limb weakness, generalised tonic- } \\
\text { clonic seizure }\end{array}$ \\
\hline $\begin{array}{l}\text { Moriguchi et } \\
\text { al. } 2020\end{array}$ & $24, \mathrm{M}$ & Case report & 1 & +9 & $\begin{array}{l}\text { consciousness disturbance, transient } \\
\text { generalized } \\
\text { seizures for about a minute }\end{array}$ \\
\hline $\begin{array}{l}\text { Atere et al. } \\
2020\end{array}$ & 46, M & Case report & 1 & +3 & $\begin{array}{l}\text { Episode of seizures, syncope; conscious after } \\
30 \text { seconds; an involuntary loss of feces }\end{array}$ \\
\hline \multirow{2}{*}{$\begin{array}{l}\text { Somani et al. } \\
2020\end{array}$} & 49, F & Case report & 1 & -3 & Case 1: altered mental status, seizure \\
\hline & 73, F & Case report & 1 & +1 & $\begin{array}{l}\text { Case 2: Persistent face and arm myoclonus } \\
\text { with worsening altered mental status (status } \\
\text { epilepticus) }\end{array}$ \\
\hline $\begin{array}{l}\text { Fasano et al. } \\
2020\end{array}$ & $54, \mathrm{M}$ & Case report & 1 & +7 & $\begin{array}{l}\text { Single seizure characterized by clonic } \\
\text { movements in the right arm and loss of } \\
\text { consciousness. }\end{array}$ \\
\hline $\begin{array}{l}\text { Zanin et al. } \\
2020\end{array}$ & 54, F & Case report & 1 & Not clear & Unconscious, later unrest \\
\hline $\begin{array}{l}\text { Stefano et al. } \\
2020\end{array}$ & 56, F & Case report & 1 & +18 & Agitation \\
\hline $\begin{array}{l}\text { Dixon et al. } \\
2020\end{array}$ & 59, M & Case report & 1 & +10 & $\begin{array}{l}\text { Vacant staring, speech arrest, flexion of both } \\
\text { shoulders and a brief witnessed generalized } \\
\text { tonic-clonic seizure (GTCS), followed by } \\
\text { postictal state }\end{array}$ \\
\hline $\begin{array}{l}\text { Sohal et al. } \\
2020\end{array}$ & $72, \mathrm{M}$ & Case report & 1 & +2 & $\begin{array}{l}\text { Multiple episodes of persistent tonic colonic } \\
\text { movements of upper and lower extremities }\end{array}$ \\
\hline $\begin{array}{l}\text { Elgamasy et } \\
\text { al. } 2020\end{array}$ & 73, F & Case report & 1 & +2 & $\begin{array}{l}\text { Painful muscle stiffening and twitching in the } \\
\text { left arm and leg }\end{array}$ \\
\hline \multirow[t]{2}{*}{$\begin{array}{l}\text { Hepburn et } \\
\text { al. } 2020\end{array}$} & $76, \mathrm{M}$ & Case report & 1 & +2 & $\begin{array}{l}\text { Multiple episodes of left upper extremity clonic } \\
\text { activity and worsening encephalopathy }\end{array}$ \\
\hline & $82, \mathrm{M}$ & Case report & 1 & +15 & Right eyelid and facial twitching \\
\hline $\begin{array}{l}\text { Farhadian et } \\
\text { al. } 2020\end{array}$ & 78, F & Case report & 1 & +2 & $\begin{array}{l}\text { Sudden-onset uncontrolled limb movements } \\
\text { with ocular deviation followed by several } \\
\text { minutes of unresponsiveness. }\end{array}$ \\
\hline $\begin{array}{l}\text { Galanopoulou } \\
\text { et al. } 2020\end{array}$ & $\begin{array}{l}\text { Age: } 63.23 \pm 11.9 \\
(30-83)\end{array}$ & $\begin{array}{l}\text { Case series } \\
\text { (retrospective) }\end{array}$ & $11(64.7 \%)$ & NA & Motor seizure like events \\
\hline $\begin{array}{l}\text { Morassi et al. } \\
2020\end{array}$ & $76, \mathrm{~F}$ & Case series & 1 & +10 & $\begin{array}{l}\text { Transient loss of consciousness, followed by } \\
\text { confusion }\end{array}$ \\
\hline $\begin{array}{l}\text { Garazzino et } \\
\text { al. } 2020\end{array}$ & 5, not mentioned & $\begin{array}{l}\text { Multicentre cross- } \\
\text { sectional (prospective) }\end{array}$ & $2(1.2)$ & 1.6 & Febrile seizure \\
\hline $\begin{array}{l}\text { Mao et al. } \\
2020\end{array}$ & $58.2 \pm 15.0$ & $\begin{array}{l}\text { Case series } \\
\text { (retrospective } \\
\text { observational) }\end{array}$ & $1(0.5)$ & NA & $\begin{array}{l}\text { Sudden onset of limb twitching, foaming in the } \\
\text { mouth, and loss of consciousness, lasted for } 3 \\
\text { minutes. }\end{array}$ \\
\hline $\begin{array}{l}\text { Pinna et al. } \\
2020\end{array}$ & 59.6 & $\begin{array}{l}\text { Case series } \\
\text { (retrospective } \\
\text { observational) }\end{array}$ & $13(26)$ & NA & Not available \\
\hline
\end{tabular}


Table 2: Diagnostic findings, interventions, and limitations

Author, year $\quad$ EEG find

$\begin{aligned} & \text { Lyons et al., Normal } \\ & 2020\end{aligned}$

Moriguchi et Not performed
al., 2020

Atere et al 2020

Somani et al., 2020 2020
Frequent (4-6/hour) cyclical seizures emanating from left fronto-central regions

Frequent (5/hour) cyclical seizures emanating from left central regions

Fasano et al., Normal and right fronto-

Head CT /MRI
findings
CT: Normal; MRI: Mild
mucosal thickening in
the sphenoid sinus

the sphenoid sinus

CT: Normal; MRI: Hyperintensity along the
wall of inferior horn of right lateral ventricle.

Fluid-attenuated inversion recovery (FLAIR) images showed hyperintense signal changes in the right mesial hippocampus with slight hippocampal atrophy.

Normal

Normal

CT: Normal, MRI: Not performed

CT: Normal; MRI: Not performed temporal lobe and

CSF analysis/
CSF PCR for
SARS-CoV2

Lymphocytic pleocystosis (21 cells/mm3, $99 \%$ mononuclear, 1\% polymorphs);

PCR Negative Normal; PCR

positive

Right lateral ventriculitis and encephalitis mainly on right mesial lobe and hippocampus

(Anti

epileptic

drugs)

Levetiraceta
Potential limitations

Levetiracetam Meningoencephalitis No known limitations Survived

EEG not performed, no follow up information
Alive during reporting of the case
Not performed Not administered
SARS-CoV-2 associated neurological symptoms
Not performed

orazepam, De novo status Levetiracetam epilepticus

Lorazepam, New-onset refractory levetiracetam, status epilepticus lacosamide, (NORSE) phenytoin, midazolam

Not administered

First focal motor seizure

No EEG, SARS-CoV- Survived 2 PCR in CSF; CSF

PCR for other viruses was done to rule out as DD

No CSF Survived

investigations(analysis, PCR), CSF PCR was performed to rule out other viral infections as DD

No CSF

Passed investigations(analysis, away PCR), CSF PCR was performed to rule out other viral infections as DD

No CSF investigations(analysis, PCR); CSF PCR for other viruses was not performed to rule out as DD, Anti epileptic drug was not administered

Normal; PCR Lacosamide, CNS involvement and negative levetiracetam, demyelinating lesions phenytoin associated with SARS-

No known limitations

Survived frontotemporal region and diffusing in

CT: Normal, MR periventricular white matter. Lesions present in bulbo-medullary junction (cervical and dorsal spinal cord)

Stefano et al., contralateral hemisphere

\section{CT: Not performed;}

Intermittent onset of 4 $\mathrm{Hz}$ rhythms over the bilateral parasagittal regions, lasting from $5 \mathrm{~s}$ to maximum $25 \mathrm{~s}$.

punctiform signal voids in bilateral juxtacortical white matter, corpus callosum, and internal capsule, compatible with cerebral microbleeds, without any ischemic or necrotizing lesion.

\section{CoV-2}

Increased protein level (1.31 g/l) and

Immunoglobulins; PCR negative
Sedatives (not Focal injury in the mentioned) absence of encephalopathy, critical illness-associated cerebral microbleeds (related to cytokine release syndrome)
CT not performed; standard CSF virology PCR was not done for other viruses to rule out as DD 
Dixon et al., Not performed 2020

Galanopoulou et al., 2020
Sohal et al., 2020

Elgamasy et Normal al., 2020

Hepburn et al., Three focal seizures 2020

Six left temporal seizures and left temporal sharp waves which were epileptogenic. lasting approximately 30 s each arising from the right centroparietal region EEG seizures mainly in left frontaltemporal regions eventually progressed to focal status epilepticus

Farhadian et Mild generalized al.,2020 slowing in ECG
CT: Brain stem swelling, subtle intrinsic pontine hemorrhage, symmetrical hypodensities in the deep gray matter and amygdalae; MRI: Extensive, relatively symmetrical changes throughout the supratentorial and infratentorial compartments.

\section{CT: Chronic} microvascular ischemic changes; MRI: Not performed

CT: Mild dilatation of the lateral ventricles with prominent fissures and sulci. Scattered deep white matter hypodensities, MRI: dilated ventricular system with a patent and prominent aqueduct of Sylvius

Normal

CT: Hypodensities within the supratentorial white matter, consistent

with mild microvascular disease but without acute intracranial lesion; MRI: Not performed No CT, MRI: atrophy and patchy periventricular and subcortical white matter hyperintensities

Sporadic epileptiform Not performed discharges present $7(41.18 \%)$
Increased protein Levetiracetam

concentration (2.3

g/L); PCR

negative

$\begin{array}{ll}\text { Not performed } & \begin{array}{l}\text { Levetiracetam, } \\ \text { valproate }\end{array} \\ \text { encephalitis }\end{array}$

Normal, slightly elevated leukocytes $(0.5$ per cubic millimeter); not performed

magnesium, Focal epilepsy, chronic levetiracetam small vessel ischemia lacosamide, clobazam

Not performed

Levetiracetam Focal seizure, comorbidity

Not performed

Levetiracetam

Status epilepticus, brain damage

\section{CSF}

inflammation;

inflammatory

cytokines present,

350 red cells/uL, protein $43 \mathrm{mg} / \mathrm{dL}$; PCR negative
Patient passed away, Passed away brain stem; hemorrhagic ANE

\author{
No SARS-CoV-2 PCR Passed \\ in CSF; standard CSF away \\ virology PCR was not \\ done for other viruses \\ to rule out as DD \\ patient passed away, \\ no follow up \\ No SARS-CoV-2 PCR Survived \\ in CSF; standard CSF \\ virology PCR was not \\ done for other viruses \\ to rule out as DD
}

\footnotetext{
CT: hypodense area $(5 \mathrm{~mm})$ in the head of the right caudate nucleus referable to a lacunar infarction. MRI: a small rounded area of diffusion restriction on the left pre-rolandic gyrus

Morassi et al., Recurrent sharp slow waves over the left temporal regional observation on the right homologous regions
} Not performed

Sedatives, antiseizure medications (ASMs) Normal; PCR not Levetiracetam $\begin{aligned} & \text { for seizures. } \\ & \text { encephalopathy, } \quad \text { No SARS-CoV-2 PCR Survived }\end{aligned}$ performed characterized by focal seizures

\section{in CSF; CSF PCR for}
other viruses was not
done to rule out as DD

Myoclonic seizures, abnormal tremulous movements concerning for seizure, motor seizures, abnormal movements or shaking movements, concerning
No treatment data was Survived available towards seizure management
No SARS-CoV-2 PCR Passed in CSF; CSF PCR for done to rule out as DD

No SARS-CoV-2 PCR Passed in CSF; CSF PCR for away other viruses was not done to rule out as DD

Scanty Not neurological/diagnostic applicable work-up 
JBS 2021;8(1):33-44

Journal of Biomedical Sciences

Epileptogenesis in COVID-19

\begin{tabular}{|c|c|c|c|c|c|c|c|}
\hline $\begin{array}{l}\text { Garazzino } \\
\text { et al., } 2020\end{array}$ & Not performed & Not performed & Not performed & $\begin{array}{l}\text { Not } \\
\text { mentioned }\end{array}$ & $\begin{array}{l}\text { Non-encephalopathic } \\
\text { seizure }\end{array}$ & $\begin{array}{l}\text { Scanty } \\
\text { neurological/diagnostic } \\
\text { work-up }\end{array}$ & $\begin{array}{l}\text { Not } \\
\text { applicable }\end{array}$ \\
\hline $\begin{array}{l}\text { Mao et al., } \\
\text { 2020(a) }\end{array}$ & Not performed & Not performed & Not performed & Not clear & $\begin{array}{l}\text { SARS-CoV-2 induced } \\
\text { seizure }\end{array}$ & $\begin{array}{l}\text { Scanty } \\
\text { neurological/diagnostic } \\
\text { work-up }\end{array}$ & $\begin{array}{l}\text { Not } \\
\text { applicable }\end{array}$ \\
\hline $\begin{array}{l}\text { Pinna et al., } \\
2020\end{array}$ & Not available & Not available & Not available & $\begin{array}{l}\text { Not } \\
\text { applicable }\end{array}$ & $\begin{array}{l}\text { Seizure was more } \\
\text { prominent in patients } \\
\text { with COVID-19 } \\
\text { symptoms as first onset, } \\
\text { other than neurological } \\
\text { symptoms }\end{array}$ & $\begin{array}{l}\text { Retrospective approach } \\
\text { and patient selection } \\
\text { bias, a full neurological } \\
\text { evaluation was not } \\
\text { done, no long-term } \\
\text { follow-up and outcome } \\
\text { data were unavailable }\end{array}$ & $\begin{array}{l}\text { Not } \\
\text { applicable }\end{array}$ \\
\hline
\end{tabular}

NA-not applicable

SE-status epilepticus

ANE-acute necrotizing encephalopathy

NORSE-new-onset refractory status epilepticus

ASMs-antiseizure medications

DD-differential diagnosis

\section{Discussion}

We are now passing through a tough time due to the SARSCoV-2 pandemic affected almost all the countries [4]. Previous outbreaks of Coronaviruses showed potential for CNS invasion, neuronal infection, and cytokines' entry along with immune cells in brain tissue. Human coronavirus OC43, a single-stranded RNA virus, can affect neurons and cause pervasive destruction [31, 32]. In a study of 70 patients infected with MERS-CoV, showed epileptic seizures and altered mental state(33). SARS-CoV-2 possess high homology with other coronavirus strains, so in this current pandemic neurologists and medical practitioners face challenges to confront the central and peripheral nervous systems manifestations. An updated systematic review may enlighten the spectrum of epileptic seizure for the diagnosis of SARS-CoV-2 infection, helping clinicians understand the underlying mechanism to start intervention earlier.

\section{Prevalence and management of seizures associated clinical manifestations}

In this study, we observed that evidence of seizures and epilepsy is closely associated. However, articles are scarce. Moriguchi et al. documented the first reported case of seizures in COVID-19 patients [11]. Earlier instances of coronavirus infections showed the potential for seizure. A study by Saad M showed that six patients $8.6 \%$ have a seizure onset in the Middle East respiratory syndrome (MERS)-CoV infection [33]. On average, the interval of the infection and onset of symptoms is 3-5 days, but it may go up to 10 days (Table-1).

Seizure was less commonly observed in the study by Ling Mao, 2020, where $1(0.5 \%)$ case was reported. The authors acknowledged that clinical outcomes were unavailable during the time of analysis because of the patients' hospitalization [5]. Whereas others documented more number of cases [22, 25]. We observed that most common clinical presentations towards seizure amongst COVID-19 victims were status epilepticus, tonic colonic movements, and loss of consciousness. According to a series of COVID19 patients from the USA, seizure events occurred in 11 (64.7\%) of the patients. Authors reported gaze deviation, motor seizure-like events such as myoclonic seizures, abnormal tremulous movements concerning seizure, motor seizures, abnormal movements, and associated these events with new onset of encephalopathy. These symptoms may arise due to COVID-19 infection as a consequence of damage to the nervous system, alteration in metabolic activities, hypoxia, and organ failure. The presence of frontal sharp waves as epileptic discharge indicated frontal epileptogenic anomaly, which authors connected with the nasopharyngeal mucosal entry of SARS-CoV-2 or via the olfactory nerve [22] . Mao et al reported $14.8 \%$ patients with severe COVID-19 disease, displayed encephalopathy [5].

Lorazepam, Levetiracetam are the commonest seizure management drugs used $[10,11,13,15,17-19,23]$. Other drugs namely lacosamide, phenytoin, midazolam [13, 15], valproate [18], magnesium, lacosamide, clobazam [19] also used.

Probable mechanism of seizure in SARS-CoV-2 patients Infection in CNS is the origin of unprovoked seizure and epilepsy. Viral encephalitis is associated with the development of seizures may go up to $22 \%$ [34]. Encephalitis is observed in SARS-CoV-2 infection is associated with seizures in its acute phase $[10,11,16,18$, $21,23]$. The toxins generated by SARS-CoV-2 and inflammatory cytokines by the brain [35] ignite a vicious cycle of inflammation resulting in a hyperexcitable state for neurons. This leads to the activation of the glutaminergic receptor via neurotransmitter glutamate, which heavily implicates anomalous signalling leading to acute epileptic seizures [35, 36]. Stephano et al reported focal injury in absence of encephalopathy and cerebral microbleeds - a result of cytokine release [16], whereas others reported cytokine storm [21] with encephalopathy [18]. Past researchers connected status epilepticus (SE) induced glutamate release and excessive stimulation of glutaminergic receptors and N-methyl-D-aspartate receptors (NMDARS) [37, 38], linked with seizure and neurological morbidity in SARS-CoV-2 outbreak [12, 13, 20]. 
Electrolyte imbalance was the less likely cause of new onset of seizures, observed in two of the reports, but a clear indication towards encephalitis and normocapnic hypoxia as a cause [12, 15]. Dixon et al reported acute necrotizing encephalopathy with rapid progression of seizures and reduced consciousness [17].

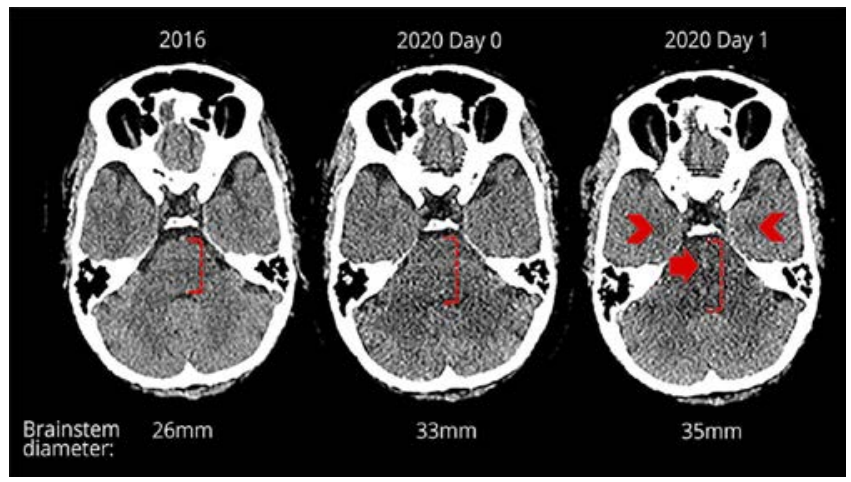

Figure 3: Head CT findings from a SARS-CoV-2 infected patient with acute necrotizing encephalopathy [17].

Axial CT head images on different dates (left to right) 2016, 2020 day 0, day 1 follow up. Early admission CT demonstrates subtle new swelling of the brain stem which progressed on follow-up. Fig 3c shows swelling with new central hemorrhagic foci (closed arrow) and symmetrical hypodensities in both amygdalae (chevrons) [17].

There may be a possible role of cytotoxic granules of CD8+ $\mathrm{T}$ cells that overexcites $\mathrm{N}$-methyl-D-aspartate receptor (NMDA) in the process of immune reactions, substantially contributing to neuronal degenerations [39]. Most of the viral infections increase $\mathrm{T}$ cell populations in brains [40, 41]. Lyons reported Lymphocytic pleocystosis (21 cells/mm3, $99 \%$ mononuclear, $1 \%$ polymorphs) is indicative of this [10]. Interleukin-12 (IL-12), secreted by macrophages and microglia [42, 43] involved in potential CNS damage in Kainic acid (KA) induced seizures [44].

\section{SARS-Cov-2 and neuroinvasion}

The underlying mechanisms of viral transmissions to CNS involves $\mathrm{BBB}$ and modulates functional ramifications. There are two possible routes - hematological and neurological are available for the SARS-CoV-2 entry to the CNS. In the hematologic route, the virus crosses the specialized brain microvascular endothelial cells (BMECs) of the BBB either directly or by using the infected cells of the reticuloendothelial system as a vehicle through the paracellular route(26). Circulating lymphocytes may be another possibility for the hematological invasion [11]. COVID virus is capable of direct BBB penetration and meningeal inflammation reported by Tohidpour et al., 2017 [27].

Structurally endfeet of the astrocytes covers intracranial blood vessels [45]. Astrocyte mediated endocytic route of
Tick-borne encephalitis virus (TBEV) and Zika virus (ZIKV) is well documented [28,29]. TBEV enters via clathrin-dependent endocytosis, which resembles with entry pattern for other family members like West Nile virus, Dengue virus, Hepatitis C virus, and Bovine Viral Diarrhoea virus [29] and another coronavirus, porcine haemagglutinating encephalomyelitis (HEV67) [30].

In the neurologic route, retrograde axonal transport through the specific peripheral nerves is the key route of SARSCoV-2 transmission to the CNS. Olfactory epithelium and nerve fibers play a vital role in this viral transmission [46]. The trans-synaptic viral transfer is reported for other CoVs clathrin-dependent endocytotic/exocytotic pathway. Although SARS-CoV-2 enters through BBB in Nervous system, interestingly except one case study [11] all tested SARS-CoV-2 PCR in CSF was negative in our review [5, 10, 12-25].

Diminished viral RNA in the brain in autopsy studies (7 out of 22) of SARS-CoV-2 related fatality is suggestive of it [47]. There is a possibility that early stages of infections may not allow viral entry in CNS but causes neuroinflammation. So COVID-19 treatment should be oriented towards host-inflammation. Farhadian et al. reported increased Monocyte Chemoattractant Protein1(MCP-1), a key chemokine in CSF - a clear indication of deployment of inflammatory infiltrate into the nervous tissue [21].

\section{Conclusion}

COVID-19 infects nervous system which causes the new onset of epileptic seizures is an important aspect of diagnosis. Cerebrovascular diseases, encephalitis, demyelinating lesions, cytokine storm are possible underlying pathology for epileptogenicity. Seizure amongst hospitalized patients varied from mild to life-threatening complications, such as hemorrhagic acute necrotizing encephalopathy (ANE). The neuroinflammatory potential unveils the viral entry through hematologic and neurogenic route and underpin existing knowledge. More evidence from cohort studies with complete diagnostic findings and differential diagnosis will strengthen the association of COVID-19 virus with an epileptic seizure.

We believe our work's novelty lies in the breadth of coverage, guiding neurologists by cumulative evidence of seizure associated with neurological damage from a practical point of view. However, we humbly acknowledge the shortfalls. First, we used mostly single case reports and relatively small case series which restrict to generalize our findings. Secondly, due to the patient's critical condition or morbidity, it was not possible to follow-up even to perform CT/MRI scan and CSF analysis in some studies we listed. Although number of studies are relatively less and predominance of suboptimal level of evidence, still sporadic epileptic seizure episodes indicates encephalopathy, brain damage in SARS-CoV-2 infection. 


\section{Abbreviations}

acute necrotizing encephalopathy (ANE), acute respiratory distress syndrome (ARDS), blood-brain barrier (BBB), brain microvascular endothelial cells (BMECs), CD8 (cluster of differentiation 8), Central nervous system (CNS) Cerebrospinal fluid (CSF), Computed Tomography (CT) Coronavirus disease 2019 (COVID-19), electroencephalogram (EEG), Interleukin (IL), Kainic acid (KA), Magnetic Resonance Imaging (MRI), Middle East respiratory syndrome coronavirus (MERS-CoV), monocyte Chemoattractant Protein-1(MCP-1), N-methyl-D-aspartate receptor (NMDA), novel coronavirus (2019-nCoV), polymerise chain reaction (PCR), porcine haemagglutinating encephalomyelitis (HEV67), Preferred Reporting Items for Systematic Review and Meta-Analysis (PRISMA), reticuloendothelial system (RE), Ribonucleic Acid (RNA), Severe acute respiratory syndrome coronavirus-2(SARS-CoV-2), status epilepticus (SE), Tickborne encephalitis virus (TBEV), Zika virus (ZIKV)

\section{Authors' contribution}

a. Study planning: BR

b. Literature search: BR, IB

c. Manuscript writing: BR, IB

d. Manuscript revision: BR, IB

e. Final approval: BR, IB

f. Agreement to be accountable for all aspects of the work: BR, IB

\section{Funding}

No funding has been obtained to conduct the study.

\section{Availability of data and materials}

All data underlying the results are available as part of the article.

\section{Competing interests}

None declared.

\section{Publisher's Note}

NHRS remains neutral with regard to jurisdictional claims in published maps and institutional affiliations.

The publisher shall not be legally responsible for any types of loss, actions, claims, proceedings, demand or costs or damages whatsoever or howsoever caused arising directly or indirectly in connection with or arising out of the use of this material.

\section{Author information}

${ }^{1}$ Dr Bedanta Roy, Senior Lecturer, Department of Physiology, Faculty of Medicine, Quest International University, Ipoh, Perak, Malaysia. ORCID

${ }^{2}$ Dr Indrajit Banerjee, Associate Professor, Department of Pharmacology, Seewoosagur Ramgoolam Medical College, Belle Rive, Mauritius. ORCID

\section{References}

1. Perlman S. Another Decade, Another Coronavirus. N Engl J Med. 2020 Feb 20;382(8):760-762.

https://doi.org/10.1056/NEJMe2001126

2. Wang C, Horby PW, Hayden FG, Gao GF. A novel coronavirus outbreak of global health concern. The Lancet. 2020;395(10223):470-3. https://doi.org/10.1016/S0140-6736(20)30185-9

3. Huang C, Wang Y, Li X, Ren L, Zhao J, Hu Y, et al. Clinical features of patients infected with 2019 novel coronavirus in Wuhan, China. The lancet. 2020;395(10223):497-506. https://doi.org/10.1016/S0140-6736(20)30183-5

4. Organization WH. Novel Coronavirus (2019nCoV): situation report, 3. 2020. [online 2021] [cited 12 Jan 2021].

Available from: URL: https://apps.who.int/iris/handle/10665/330762

5. Mao L, Jin H, Wang M, Hu Y, Chen S, He Q, et al. Neurologic manifestations of hospitalized patients with coronavirus disease 2019 in Wuhan, China. JAMA neurology. 2020;77(6):683-90. https://doi.org/10.1001/jamaneurol.2020.1127

6. Wang D, Hu B, Hu C, Zhu F, Liu X, Zhang J, et al. Clinical characteristics of 138 hospitalized patients with 2019 novel coronavirus-infected pneumonia in Wuhan, China. Jama. 2020;323(11):1061-9.

https://doi.org/10.1001/jama.2020.1585

7. Tsai L, Hsieh S, Chang Y. Neurological manifestations in severe acute respiratory syndrome. Acta neurologica Taiwanica. 2005;14(3):113.

8. Lau K-K, Yu W-C, Chu C-M, Lau S-T, Sheng B, Yuen K-Y. Possible central nervous system infection by SARS coronavirus. Emerging infectious diseases. 2004;10(2):342.

https://doi.org/10.3201/eid1002.030638

9. Moher D, Liberati A, Tetzlaff J, Altman DG, Group P. Preferred reporting items for systematic reviews and meta-analyses: the PRISMA statement. PLoS med. 2009;6(7):e1000097. https://doi.org/10.1371/journal.pmed.1000097

10. Lyons S, O'Kelly B, Woods S, Rowan C, Brady D, Sheehan G, et al. Seizure with CSF lymphocytosis as a presenting feature of COVID19 in an otherwise healthy young man. SeizureEuropean Journal of Epilepsy. 2020;80:113-4. https://doi.org/10.1016/j.seizure.2020.06.010

11. Moriguchi T, Harii N, Goto J, Harada D, Sugawara H, Takamino J, et al. A first case of meningitis/encephalitis associated with SARSCoronavirus-2. Int J Infect Dis. 2020 May;94:5558. https://doi.org/10.1016/j.ijid.2020.03.062 
12. Atere M, Singh S, Arora K, Khan Z, Muzangwa L, Bhavsar U, et al. COVID-19: The Case of Three Patients with the Same Diagnosis but Different Clinical and Laboratory Features. Case Rep Med. 2020 May 24;2020:9185041 https://doi.org/10.1155/2020/9185041

13. Somani S, Pati S, Gaston T, Chitlangia A, Agnihotri S. De Novo Status Epilepticus in patients with COVID-19. Ann Clin Transl Neurol. 2020 Jul;7(7):1240-1244. https://doi.org/10.1002/acn3.51071

14. Fasano A, Cavallieri F, Canali E, Valzania F. First motor seizure as presenting symptom of SARS-CoV-2 infection. Neurol Sci. 2020 Jul;41(7):1651-1653.

https://doi.org/10.1007/s10072-020-04460-z

15. Zanin L, Saraceno G, Panciani PP, Renisi G, Signorini L, Migliorati $\mathrm{K}$, et al. SARS-CoV-2 can induce brain and spine demyelinating lesions. Acta Neurochirurgica. 2020:1-4. https://doi.org/10.1007/s00701-020-04374-X

16. De Stefano $P$, Nencha U, De Stefano L, Mégevand $\mathrm{P}$, Seeck $\mathrm{M}$. Focal EEG changes indicating critical illness associated cerebral microbleeds in a Covid-19 patient. Clin Neurophysiol Pract. 2020 Jun 10;5:125-129. https://doi.org/10.1016/j.cnp.2020.05.004

17. Dixon L, Varley J, Gontsarova A, Mallon D, Tona F, Muir D, et al. COVID-19-related acute necrotizing encephalopathy with brain stem involvement in a patient with aplastic anemia. Neurol Neuroimmunol Neuroinflamm. 2020 May 26;7(5):e789. https://doi.org/10.1212/NXI.0000000000000789

18. Sohal S, Mansur M. COVID-19 Presenting with Seizures. IDCases. 2020 May 1;20:e00782. https://doi.org/10.1016/j.idcr.2020.e00782

19. Elgamasy S, Kamel MG, Ghozy S, Khalil A, Morra ME, Islam SMS. First case of focal epilepsy associated with SARS-coronavirus-2. J Med Virol. 2020 Oct;92(10):2238-2242. https://doi.org/10.1002/jmv.26113

20. Hepburn M, Mullaguri N, George P, Hantus S, Punia V, Bhimraj A, et al. Acute Symptomatic Seizures in Critically Ill Patients with COVID19: Is There an Association? Neurocritical Care. 2020:1. https://doi.org/10.1007/s12028-020-01006-1

21. Farhadian S, Glick LR, Vogels CBF, Thomas J, Chiarella J, Casanovas-Massana A, et al. Acute encephalopathy with elevated CSF inflammatory markers as the initial presentation of COVID-19. BMC Neurol. 2020 Jun 18;20(1):248. https://doi.org/10.1186/s12883-020-01812-2

22. Galanopoulou AS, Ferastraoaru V, Correa DJ, Cherian K, Duberstein S, Gursky J, et al. EEG findings in acutely ill patients investigated for SARS-CoV-2/COVID-19: A small case series preliminary report. Epilepsia Open. 2020 May 17;5(2):314-324. https://doi.org/10.1002/epi4.12399

23. Morassi M, Bagatto D, Cobelli M, D'Agostini S, Gigli GL, Bnà C, Vogrig A. Stroke in patients with SARS-CoV-2 infection: case series. J Neurol. 2020 Aug;267(8):2185-2192. https://doi.org/10.1007/s00415-020-09885-2

24. Garazzino S, Montagnani C, Donà D, Meini A, Felici E, Vergine $\mathrm{G}$, et al. Multicentre Italian study of SARS-CoV-2 infection in children and adolescents, preliminary data as at 10 April 2020. Eurosurveillance. 2020;25(18):2000600. https://doi.org/10.2807/15607917.ES.2020.25.18.2000600

25. Pinna P, Grewal P, Hall JP, Tavarez T, Dafer RM, Garg R, et al. Neurological manifestations and COVID-19: Experiences from a tertiary care center at the Frontline. J Neurol Sci. 2020 Aug 15;415:116969. https://doi.org/10.1016/j.jns.2020.116969

26. Bohmwald K, Galvez N, Ríos M, Kalergis AM. Neurologic alterations due to respiratory virus infections. Frontiers in cellular neuroscience. 2018;12:386. https://doi.org/10.3389/fncel.2018.00386

27. Tohidpour A, Morgun AV, Boitsova EB, Malinovskaya NA, Martynova GP, Khilazheva ED, et al. Neuroinflammation and infection: molecular mechanisms associated with dysfunction of neurovascular unit. Frontiers in cellular and infection microbiology. 2017;7:276. https://doi.org/10.3389/fcimb.2017.00276

28. Jorgačevski J, Korva M, Potokar M, Lisjak M, Avšič-Županc T, Zorec R. ZIKV strains differentially affect survival of human fetal astrocytes versus neurons and traffic of ZIKVladen endocytotic compartments. Scientific reports. 2019;9(1):1-14. https://doi.org/10.1038/s41598-019-44559-8

29. Zorec R, Županc TA, Verkhratsky A. Astrogliopathology in the infectious insults of the brain. Neuroscience Letters. 2019;689:56-62. https://doi.org/10.1016/j.neulet.2018.08.003

30. Li YC, Bai WZ, Hirano N, Hayashida T, Taniguchi T, Sugita Y, et al. Neurotropic virus tracing suggests a membranous-coating-mediated mechanism for transsynaptic communication. Journal of Comparative Neurology. 2013;521(1):203-12. https://doi.org/10.1002/cne.23171

31. Arbour N, Côté G, Lachance C, Tardieu M, Cashman NR, Talbot PJ. Acute and persistent infection of human neural cell lines by human 
coronavirus OC43. Journal of virology. 1999;73(4):3338-50.

https://doi.org/10.1128/JVI.73.4.3326-3337.1999

32. Jacomy H, Talbot PJ. Vacuolating encephalitis in mice infected by human coronavirus OC43. Virology. 2003;315(1):20-33. https://doi.org/10.1016/S0042-6822(03)00323-4

33. Saad M, Omrani AS, Baig K, Bahloul A, Elzein F, Matin MA, et al. Clinical aspects and outcomes of 70 patients with Middle East respiratory syndrome coronavirus infection: a single-center experience in Saudi Arabia. International Journal of Infectious Diseases. 2014;29:301-6.

https://doi.org/10.1016/j.ijid.2014.09.003

34. Schmutzhard E. Viral infections of the CNS with special emphasis on herpes simplex infections. Journal of neurology. 2001;248(6):469-77. https://doi.org/10.1007/s004150170155

35. Libbey JE, Kirkman NJ, Smith MC, Tanaka T, Wilcox KS, White HS, et al. Seizures following picornavirus infection. Epilepsia.

2008;49(6):1066-74.

https://doi.org/10.1111/j.15281167.2008.01535.x

36. Singhi P. Infectious causes of seizures and epilepsy in the developing world. Developmental Medicine \& Child Neurology. 2011;53(7):600-9. https://doi.org/10.1111/j.14698749.2011.03928.x

37. McDonough JH Jr, Shih TM. Neuropharmacological mechanisms of nerve agent-induced seizure and neuropathology. Neurosci Biobehav Rev. 1997 Sep;21(5):559-79. https://doi.org/10.1016/s0149-7634(96)00050-4

38. Dorandeu F, Barbier L, Dhote F, Testylier G, Carpentier P. Ketamine combinations for the field treatment of soman-induced self-sustaining status epilepticus. Review of current data and perspectives. Chemico-biological interactions. 2013;203(1):154-9.

https://doi.org/10.1016/j.cbi.2012.09.013

39. Malipiero U, Heuss C, Schlapbach R, Tschopp J, Gerber U, Fontana A. Involvement of the $\mathrm{N}$-methyl-D-aspartate receptor in neuronal cell death induced by cytotoxic $\mathrm{T}$ cell-derived secretory granules. European journal of immunology. 1999;29(10):3053-62.

https://doi.org/10.1002/(SICI)1521-

4141(199910)29:10<3053::AID-

IMMU3053>3.0.CO;2-I

40. Getts MT, Kim BS, Miller SD. Differential outcome of tolerance induction in naive versus activated Theiler's virus epitope-specific CD8+ cytotoxic $\mathrm{T}$ cells. Journal of virology. 2007;81(12):6584-93.
https://doi.org/10.1128/JVI.00008-07

41. Nair A, Hunzeker J, Bonneau RH. Modulation of microglia and CD8+ $\mathrm{T}$ cell activation during the development of stress-induced herpes simplex virus type- 1 encephalitis. Brain, behavior, and immunity. 2007;21(6):791-806. https://doi.org/10.1016/j.bbi.2007.01.005

42. Aloisi F, Penna G, Cerase J, Iglesias BM, Adorini L. IL-12 production by central nervous system microglia is inhibited by astrocytes. The Journal of Immunology. 1997;159(4):1604-12.

43. Olson JK, Girvin AM, Miller SD. Direct activation of innate and antigen-presenting functions of microglia following infection with Theiler's virus. Journal of virology. 2001;75(20):9780-9. https://doi.org/10.1128/JVI.75.20.97809789.2001

44. Chen Z, Duan R-S, Concha QH, Wu Q, Mix E, Winblad B, et al. IL-12p35 deficiency alleviates kainic acid-induced hippocampal neurodegeneration in $\mathrm{C} 57 \mathrm{BL} / 6$ mice. Neurobiology of disease. 2004;17(2):171-8. https://doi.org/10.1016/j.nbd.2004.07.018

45. Verkhratsky A, Nedergaard M. Physiology of astroglia. Physiological reviews. 2018;98(1):239389.

https://doi.org/10.1152/physrev.00042.2016

46. Swanson II PA, McGavern DB. Viral diseases of the central nervous system. Current opinion in virology. 2015;11:44-54. https://doi.org/10.1016/j.coviro.2014.12.009

47. Puelles VG, Lütgehetmann M, Lindenmeyer MT, Sperhake JP, Wong MN, Allweiss L, et al .Multiorgan and Renal Tropism of SARS-CoV-2. N Engl J Med. 2020 Aug 6;383(6):590-592. https://doi.org/10.1056/NEJMc2011400 